\title{
Assessment of Soil Metals Status in parts of Rivers State, Nigeria
}

\author{
*1'WANJALA, MP; ${ }^{2}$ ODOKUMA, L; ${ }^{3}$ ETELA, I; ${ }^{4}$ RAMKAT, R \\ ${ }^{I}$ Department of Biological Sciences, ${ }^{4}$ Center of Excellence in Phytochemicals, Textiles and Renewable Energy, Moi University, P. O. Box \\ 7648 30100, Eldoret, Kenya \\ ${ }^{2}$ Department of Microbiology, ${ }^{3}$ Department of Animal Science University of Port Harcourt, Nigeria \\ *Corresponding Author Email: piwanjala@gmail.com; Tele: +254725891794/+2348101149649
}

\begin{abstract}
The study evaluates levels of metals in soils of 9 locations in Port Harcourt and its environs in Rivers State in Nigeria. Composite samples were collected by random sampling from each of the 9 test locations, 3 control samples were also collected from each of the study areas. Concentration levels of (Lead) $\mathrm{Pb},(\mathrm{Copper}) \mathrm{Cu},(\mathrm{Cadmium})$ Cd, (Zinc) Zn, (Calcium) Ca, (Nickel) Ni, (Sodium) Na, (Potassium) K, (Chromium) Cr, (Magnesium) Mg, (Manganese) $\mathrm{Mn}$, and (Sulphur) $\mathrm{S}$ in soil were measured using Atomic Absorption Spectrophotometry. The obtained mean levels of $\mathrm{Pb}, \mathrm{Cu}, \mathrm{Cd}, \mathrm{Zn}, \mathrm{Ca}, \mathrm{Ni}, \mathrm{Na}, \mathrm{K}, \mathrm{Cr}, \mathrm{Mn}$ and $\mathrm{Mg}$ were $1.45 \pm 0.16,0.22 \pm 0.04,0.04 \pm 0.01,2.61 \pm 0.51,12.99 \pm 4.81,0.75 \pm 0.08$, $173.64 \pm 35.31,6.06 \pm 1.58,0.27 \pm 0.03,4.21 \pm 0.61$ and $11.87 \pm 2.10 \mathrm{ppm}$ respectively. There were significant differences in levels of $\mathrm{Pb}$ among the test and control samples ( $\mathrm{p}=.048)$. There was significant difference in levels of $\mathrm{Cu}$ among the test and control samples $(\mathrm{p}=0.001)$. There was significant difference in levels of $\mathrm{Zn}$ among the test and control samples $(\mathrm{p}=0.016)$. The study establishes that urbanization, industrialization and agricultural activities do affect the level of metals in the soils of the study areas. The pollution of soils with metals in the studied sites is within permissible limits, however, levels of $\mathrm{Zn}, \mathrm{Cd}$ and Ni should be on close monitoring to in the industrial areas and urbanized areas. The study establishes that oil and gas activities variedly affect the levels of metal pollution in urbanized, industrialized and agricultural areas.
\end{abstract}

\section{DOI: https://dx.doi.org/10.4314/jasem.v23i3.26}

Copyright: Copyright (C) 2019 Wanjala et al. This is an open access article distributed under the Creative Commons Attribution License (CCL), which permits unrestricted use, distribution, and reproduction in any medium, provided the original work is properly cited.

Dates: Received: 17 November 2018; Revised: 19 January 2019; Accepted 22 January 2019

Keywords: Anthropogenic activities, Metals, Impact, Ecosystem, Integrity

Environmental pollution is an increase in the concentration of both biological and physicochemical parameters above the environmental baseline levels. These baseline levels may be determined in the environment. Environmental pollution is an aspect of environmental degradation (United Nations Interagency Framework Team for Preventive Action, 2012). Degradation of the environment may be expeditiously influenced by; rapid economic growth, population growth, urbanization, industrialization, unrestrained agricultural activities, rising energy consumption and transportation ( $\mathrm{Li}$ and $\mathrm{Ma}, 2014$ ). Therefore, human disturbance is a primary cause of environmental degradation and loss of soil ecosystem integrity. Despite being a major source of environmental degradation, population is an important aspect of development. A big population means voluminous wastes. Population, megacities and urban slams are rapidly emerging and consequently the environment continues to receive voluminous wastes that compromise its natural status (Prasad and Kaimin, 2016). The World Bank foresees that 2.2 billion tons of wastes will be produced by 2025 , which is an increase of $69 \%$ and reflects urbanization and industrialization (Hoornweg and Bhada, 2012). It is not certain of all the areas that are contaminated in Nigeria and there is need for continuous monitoring of the environment in order to come up with the sites that are polluted. A risk assessment is thus vital for description and management of the environment. The scope of this study is limited to assess human influence on levels of physicochemical parameters in soils of Port Harcourt and its environs.

Ecological risks are of concern due to accumulation of heavy metals in the soil which compromises the soil ecosystem integrity (Islam et al., 2017), and consequently calls for more ecological risk assessment (Islam et al., 2017). Food that is contaminated with heavy metals is hazardous and can cause toxic effects on health of an ecosystem as well as humans (Balkhair \& Ashraf, 2016; Alghobar \& Suresha, 2017). Cadmium is intensively used in the industries in rechargeable batteries, paints, stabilization of plastic and in processing of $\mathrm{Zn}$ among others (Jaishankar, Tseten, Anbalagan, Mathew, \& Beeregowda, 2014). Cadmium accumulates in the environment and gets to human diet through biomagnification (Jaishankar et al., 2014). If Cd gets into the human body, it causes reproductive disfunction, hepatic and renal toxicity as

*Corresponding Author Email: piwanjala@gmail.com; Tele: +254725891794/+2348101149649 
it possesses ability to bind cysteine, glutamate and histidine (Castagnetto et al., 2002; FDA [Food and Drug Administration]; Harmanescu, Alda, Bordean, Gogoasa, \& Gergen, 2011; Jaishankar et al., 2014). Copper $(\mathrm{Cu}), \mathrm{Cr}, \mathrm{Ni}$ and $\mathrm{Zn}$ are essential for growth of existence of organisms (Jaishankar et al., 2014); (Rahman, Rahman, Reichman, Lim, \& Naidu, 2014), but if excessively consumed they become hazardous and unsafe for human health.

Chromium occurs naturally in the environment but its high occurrence is influenced by burning coal, petroleum and oil, in the processing of fertilizers and pigments and in electroplating (Jaishankar et al., 2014).

Chromium occurs in several oxidation states in the environment from $\mathrm{Cr}_{2}{ }^{+}$to $\mathrm{Cr}_{6}{ }^{+}$, where each oxidation state offers unique mechanisms of toxicity imposing damage to proteins including DNA (Jaishankar et al., 2014). Copper $(\mathrm{Cu})$ is an essential nutrient, but excess intake of $\mathrm{Cu}$ causes hepatic damage, headache, acute esophageal aches, diarrhea and vomiting (Harmanescu et al., 2011); Jaishankar et al., 2014; Rahman et al., 2014).

Excessive intake of Manganese is associated with neurotoxicity as Manganese iron deposition in Parkinsonism (FDA; Harmanescu et al., 2011). Nickel contaminates soil through atmospheric deposition, mining of metallic materials, smelting, agricultural activities and industrial activities (Jaishankar et al., 2014). Nickel (Ni) is an essential nutrient, however if consumed excessively by human can be carcinogenic (Rahman et al., 2012a).

Lead $(\mathrm{Pb})$ hardly provides for any biological roles if consumed. Lead $(\mathrm{Pb})$ has carcinogenic effects (Jaishankar et al., 2014). Lead (Pb) damages chlorophyll where its toxicity arises from its ability to replace cations including $\mathrm{Na}+\mathrm{Ca} 2+, \mathrm{Mg} 2+$ and $\mathrm{Fe} 2+$ (Harmanescu et al., 2011).

Lead $(\mathrm{Pb})$ also induces cardiovascular diseases, reduces cognitive development, tumor induction and hypertension (Harmanescu et al., 2011). Contamination of soil by Zinc (Zn) is by mining and smelting of metal, atmospheric depositions and agricultural and industrial activities (Rahman et al., 2014).

Zinc $(\mathrm{Zn})$ induces disruption of the immune system and consequently reduces immune function (Harmanescu et al., 2011).

\section{MATERIALS AND METHODS}

Description of the Study Site: This study was conducted in 9 selected areas of Port Harcourt, the Capital of Rivers State, Nigeria (Figure 1). The areas of interest were grouped into 3; urban, industrial and agricultural areas. The urban areas of interest included; GRA phase 2, Diobu- Mile 1 and Mguoba. Agricultural areas of interest included; Aluu, Eleme, Emuoha- Eu, while the industrialized areas were; Eleme which hosts the NNPC Refinery, AgbadaSPDC- flow station in a rural setting and Trans-Amadi. The characteristics and main activities (Table 1) conducted in the study areas include; drilling and mining, fishing, fish farming, horticulture, dairy farming and crop farming, industrial processing. The study areas were assigned codes as in Table 1.

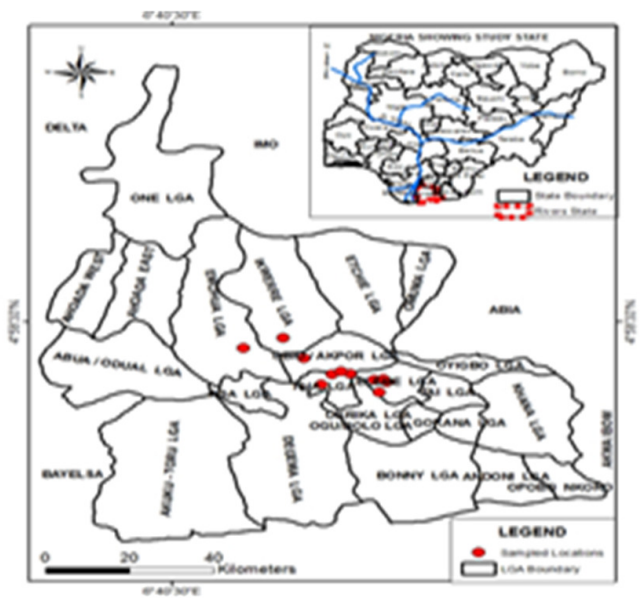

Fig 1: Map of Nigeria showing Rivers state

Sampling: Composite samples were collected by random sampling from each of the three areas; urbanized, industrialized and agricultural in the wet season (April to October 2018). Five (5) individual samples were collected following a random pattern around each test field. The five individual samples were thoroughly mixed by coning and quartering in a sterile container to attain a homogenous composite mixture. A total of 12 composite samples; A1, A2, A3, I1, I2, I3 U1, U2 and U3 as test samples, and CA, CI and $\mathrm{CU}$ as control samples (Table 1), were collected from the topsoil within a depth of 0 to $15 \mathrm{~cm}$ using a standard auger 3 times in the rainy season. Homogenized composite samples (400 gm) were then packed in polyethylene bags using a sterile wooden shovel. Samples for microbial analysis were collected using pre-sterilized materials to prevent contamination of the samples. Locations of the sampling sites were identified using a GPS and the GPS readings recorded. Samples were transported to the laboratory for analysis. 
Determination of levels of metals in soil: Concentration levels of $\mathrm{Pb}, \mathrm{Fe}, \mathrm{Cu}, \mathrm{Cd}, \mathrm{Zn}, \mathrm{Ca}, \mathrm{Ni}, \mathrm{Na}$, $\mathrm{K}, \mathrm{Cr}, \mathrm{Mg}, \mathrm{Mn}$, and $\mathrm{S}$ in soil were measured using Atomic Absorption Spectrophotometry [AAS] (APHA, 1995). The heavy metals were then measured at specified wavelengths; Lead: 283.2, Copper: 324.7, Cadmium: 228.9, Zinc: 213.9, Nickel: 341.5, Calcium: 422.7, Sodium: 589.00, Potassium: 766.5, Manganese: 279.5, Magnesium: 285.2, Chromium: 357.9 (APHA, 301A). Soil $\mathrm{pH}$ and conductivity was measured using the standard; electrical meter method (APHA, 1995).

Data Analysis: SPSS statistical software was used to analyse collected data. ANOVA was used to describe mean differences among the different sampling locations and the control samples. Means differences were described using Tukey HSD.

\section{RESULTS AND DISCUSSION}

Metals in soil: Lead: Heavy metals in agricultural soils are health risk. The mean levels of $\mathrm{Pb}$ in soil were within the WHO acceptable limit of $\leq 100$ (ppm). There was significant difference in level of $\mathrm{Pb}$ among the test and control samples $(\mathrm{p}=.048)$. Levels of $\mathrm{Pb}$ demonstrated an increasing trend in I3 (Figure 2). The highest value of $\mathrm{Pb}$ was recorded in $\mathrm{I} 3$ (Trans-Amadi); $3.50 \pm 0.88 \mathrm{ppm}$ (Table 2).

Copper: The mean levels of $\mathrm{Cu}$ in soil were within the WHO acceptable limit of $\leq 100 \mathrm{ppm}$. There was significant difference among the test and control samples $(\mathrm{p}=0.001)$. The levels of $\mathrm{Cu}$ demonstrated an upward trend in U2 (Diobu), with a mean of $1.07 \pm 0.12$ (Figure 2). The highest values of $\mathrm{Cu}$ were recorded in I3; $0.35 \pm 0.01 \mathrm{ppm}, \mathrm{CA} ; 0.29 \pm 0.12 \mathrm{ppm}$ and $\mathrm{U} 2$; $0.73 \pm 0.25 \mathrm{ppm}$ (Table 2).

Table 1: Characteristics and main activities in the selected study areas and assigned codes

\begin{tabular}{|c|c|c|c|c|}
\hline No & $\begin{array}{l}\text { Selected } \\
\text { study } \\
\text { areas }\end{array}$ & $\begin{array}{l}\text { Study area } \\
\text { coding } \\
\text { (Locations) }\end{array}$ & $\begin{array}{l}\text { Coordinates/ } \\
\text { N Latitude } \\
\text { E Longitude }\end{array}$ & $\begin{array}{l}\text { Characteristic and main } \\
\text { activities }\end{array}$ \\
\hline \multicolumn{5}{|c|}{ Agricultural areas } \\
\hline 1 & Aluu & A1 & $\begin{array}{l}4^{\circ} 56^{\prime} 11.160 \\
6^{\circ} 57^{\prime} 52.248^{\prime}\end{array}$ & Flow station \\
\hline 2 & Eleme & A2 & $\begin{array}{l}4^{\circ} 44^{\prime}, 09.874 \\
7^{\circ} 08,58.494\end{array}$ & Village close to refinery \\
\hline 3 & Emuoha & A3 & $\begin{array}{l}5^{\circ} 00^{\prime} 00.018 \\
6^{\circ} 49^{\prime} 13.032\end{array}$ & Flow station \\
\hline 4 & Control & $\mathrm{CA}$ & $\begin{array}{l}5^{\circ} 00^{\prime} 21.384^{\prime} \\
6^{\circ} 49^{\prime} 00.000\end{array}$ & $>1 \mathrm{~km}$ away from suspected areas \\
\hline \multicolumn{5}{|c|}{ Industrial areas } \\
\hline 1 & Onne & I1 & $\begin{array}{l}4^{\circ} 46^{\prime} 00.402 \\
7^{\circ} 05^{\prime} 43.092\end{array}$ & Hosts the NNPC Refinery \\
\hline 2 & Agbada & $\mathrm{I} 2$ & $\begin{array}{l}4^{\circ} 56^{\prime}, 03.444^{\prime} \\
6^{\circ} 58^{\prime} 42.060\end{array}$ & $\begin{array}{l}\text { Hosts SPDC- flow station in a rural } \\
\text { setting }\end{array}$ \\
\hline 3 & $\begin{array}{l}\text { Trans- } \\
\text { Amadi }\end{array}$ & $\mathrm{I} 3$ & $\begin{array}{l}4^{\circ} 48^{\prime} 20.455^{\prime} \\
7^{\circ} 02^{\prime} 17.646^{\prime}\end{array}$ & Schlumberger/, Hallburton \\
\hline 4 & Control & $\mathrm{CI}$ & $\begin{array}{l}4^{\circ} 47^{\prime} 13.788^{\prime} \\
7^{\circ} 07^{\prime} 44.620^{\prime}\end{array}$ & $>1 \mathrm{~km}$ away from suspected areas \\
\hline \multicolumn{5}{|c|}{ Urban areas } \\
\hline 1 & $\begin{array}{l}\text { GRA } \\
\text { phase } 2\end{array}$ & U1 & $\begin{array}{l}4^{\circ} 49^{\prime}, 53.574^{\prime} \\
6^{\circ} 59^{\prime} 45.552\end{array}$ & Inhabited areas Perecuma street \\
\hline 2 & $\begin{array}{l}\text { Diobu- } \\
\text { Mile } 1\end{array}$ & $\mathrm{U} 2$ & $\begin{array}{l}4^{\circ} 47^{\prime} 20.382^{\prime} \\
7^{\circ} 00^{\prime} 13.164\end{array}$ & Petroleum refinery \\
\hline 3 & Mguoba & U3 & $\begin{array}{l}4^{\circ} 50^{\prime} 39.864 \\
6^{\circ} 58^{\prime} \\
20.232\end{array}$ & NTA \\
\hline 4 & Control & $\mathrm{CU}$ & $\begin{array}{l}4^{\circ} 49^{\prime}, 17,040 \\
6^{\circ} 59^{\prime}, 24.168\end{array}$ & $>1 \mathrm{~km}$ away from suspected areas \\
\hline
\end{tabular}

Cadmium: The mean levels of $\mathrm{Cd}$ in soil were within the WHO acceptable limit of $\leq 3 \mathrm{ppm}$. There was no significant difference among the test and control samples $(\mathrm{p}=0.152)$. The levels of $\mathrm{Cu}$ demonstrated an upward trend in U2 (Diobu) [Figure 2]. The highest value was recorded in $\mathrm{I} 1$ (Onne); $0.06 \pm 0.01 \mathrm{ppm}$ while $\mathrm{A} 2$ (Eleme) recorded the least value of $\mathrm{Cu} ; 0.02 \pm 0.02$ ppm (Table 2).
Zinc: The mean levels of $\mathrm{Zn}$ in soil were within the WHO acceptable limit of $\leq 300 \mathrm{ppm}$. There was significant difference among the test and control samples $(\mathrm{p}=0.016)$. The levels of $\mathrm{Zn}$ demonstrated an increasing trend in I3 (Figure 2). The highest values of $\mathrm{Zn}$ were recorded in CI (Ogali); $5.42 \pm 2.85 \mathrm{ppm}$, and I3 (Trans-Amadi); 9.08 \pm 3.68 ppm while A1 recorded the least value; $0.94 \pm 0.35 \mathrm{ppm}$ (Table 2 ). 
Calcium: The mean levels of Ca in soil were within the WHO acceptable limit of $\leq 100$ (ppm). There was no significant difference among the test and control samples $(\mathrm{p}=0.314)$. The levels of Ca demonstrated an increasing trend in CI and CA (Figure 2). The highest values of $\mathrm{Ca}$ were recorded in $\mathrm{C} 1 ; 48.43 \pm 30.30$, CA; $34.32 \pm 19.65$ and $U 2 ; 43.41 \pm 41.79$ (Table 2).

Nickel: The mean levels of Ni were within the WHO acceptable limit of $\leq 50 \quad(\mathrm{ppm})$. There was no significant difference among the test and control samples $(\mathrm{p}=0.83)$. The levels of $\mathrm{Ni}$ demonstrated an upward trend in U2 (Figure 2). The highest value of $\mathrm{Ni}$ was recorded in $\mathrm{U} 2 ; 1.11 \pm 0.37$ (Table 2).

Sodium: The mean levels of $\mathrm{Na}$ in soil were within the WHO acceptable limit of $\leq 100$ (ppm). There was no significant difference among the test and control samples $(\mathrm{p}=0.311)$. The levels of $\mathrm{Na}$ demonstrated an increasing trend in U2 (Diobu) [Figure 2]. The highest values of $\mathrm{Na}$ were recorded in I2 (Agbada); 454.13 $\pm 299.01 \mathrm{ppm}$ and CU; 443.67 \pm 253.26 (Table $3)$.

Potassium: The mean levels of $\mathrm{K}$ in soil were within the WHO acceptable limit of $\leq 100$ ( $\mathrm{ppm})$. There was no significant difference among the test and control samples $(\mathrm{p}=0.401)$. The levels of $\mathrm{K}$ demonstrated an upward trend in CI and U2 (Figure 2). The highest values of $\mathrm{K}$ were recorded in $\mathrm{CI} ; 13.21 \pm 6.29$ and $\mathrm{U} 3$; 17.95 \pm 15.54 (Table 3).

Chromium: The mean level of $\mathrm{Cr}$ in soil were within the WHO acceptable limit of $\leq 100$ (ppm). There was no significant difference among the test and control samples $(\mathrm{p}=0.769)$. The levels of $\mathrm{Cr}$ demonstrated an upward trend in U2 (Figure 2). The highest values of $\mathrm{Cr}$ were recorded in CA; $0.45 \pm 0.18 \mathrm{ppm}$ and $\mathrm{U} 2$; $0.41 \pm 0.16$ ppm (Table 3).

Magnesium: The mean level of $\mathrm{Mg}$ in soil were within the WHO acceptable limit of $\leq 100$ (ppm). There was no significant difference among the test and control samples $(\mathrm{p}=0.286)$ (Figure 2). The highest mean values of $\mathrm{Mg}$ were recorded in $\mathrm{CA} ; 23.45 \pm 12.17 \mathrm{ppm}$, $\mathrm{CU} ; 22.85 \pm 14.00 \mathrm{ppm}$ and $\mathrm{U} 2 ; 23.04 \pm 7.22 \mathrm{ppm}$ (Table 3).

Manganese: The mean levels of $\mathrm{Mn}$ in soils were within the WHO acceptable limit of $\leq 2,000$ ( $\mathrm{ppm}$ ). There was no significant difference among the test and control samples $(\mathrm{p}=0.063)$. The levels of $\mathrm{Mn}$ demonstrated an increasing trend in U2 (Figure 2). The highest values of Mn were recorded in CA; 8.76 \pm 3.62 , $\mathrm{A} 3 ; 7.50 \pm 3.76$ and $\mathrm{U} 2 ; 7.50 \pm 3.28$ (Table 3 ).

Table 2: Mean concentration $( \pm \mathrm{SE})$ of heavy metals in soil

\begin{tabular}{lllllll}
\hline $\begin{array}{l}\text { Study } \\
\text { locations }\end{array}$ & Pb (ppm) & Cu (ppm) & Cd (ppm) & $\mathbf{Z n}(\mathbf{p p m})$ & $\mathbf{C a}(\mathbf{p p m})$ & $\mathrm{Ni}(\mathbf{p p m})$ \\
\hline $\mathrm{CI}$ & $1.15 \pm 0.50$ & $0.13 \pm 0.04$ & $0.06 \pm 0.01$ & $5.42 \pm 2.85$ & $48.43 \pm 30.30$ & $0.92 \pm 0.34$ \\
I1 & $1.27 \pm 0.28$ & $0.13 \pm 0.03$ & $0.04 \pm 0.01$ & $1.57 \pm 0.43$ & $7.55 \pm 5.23$ & $0.84 \pm 0.33$ \\
I2 & $0.89 \pm 0.30$ & $0.17 \pm 0.01$ & $0.04 \pm 0.02$ & $1.16 \pm 0.25$ & $3.03 \pm 1.34$ & $0.79 \pm 0.25$ \\
I3 & $3.50 \pm 0.88$ & $0.35 \pm 0.01$ & $0.05 \pm 0.02$ & $9.08 \pm 3.68$ & $2.13 \pm 0.61$ & $0.92 \pm 0.33$ \\
CA & $1.33 \pm 0.56$ & $0.29 \pm 0.12$ & $0.04 \pm 0.02$ & $2.04 \pm 0.47$ & $34.32 \pm 19.65$ & $0.43 \pm 0.13$ \\
A1 & $1.04 \pm 0.36$ & $0.17 \pm 0.00$ & $0.03 \pm 0.01$ & $0.94 \pm 0.35$ & 0.860 .31 & $0.74 \pm 0.29$ \\
A.2 & $1.44 \pm 0.52$ & $0.17 \pm 0.02$ & $0.02 \pm 0.02$ & $1.62 \pm 0.63$ & $1.44 \pm 0.27$ & $0.47 \pm 0.14$ \\
A3 & $1.37 \pm 0.48$ & $0.19 \pm 0.02$ & $0.04 \pm 0.01$ & $1.91 \pm 0.44$ & $1.69 \pm 0.25$ & $0.99 \pm 0.33$ \\
CU & $1.25 \pm 0.26$ & $0.17 \pm 0.06$ & $0.04 \pm 0.00$ & $1.50 \pm 0.59$ & $1.71 \pm 0.54$ & $0.55 \pm 0.22$ \\
U1 & $1.52 \pm 0.44$ & $0.13 \pm 0.01$ & $0.04 \pm 0.01$ & $2.04 \pm 0.45$ & $4.06 \pm 1.14$ & $0.65 \pm 0.26$ \\
U2 & $1.71 \pm 0.23$ & $0.73 \pm 0.25$ & $0.04 \pm 0.01$ & $2.80 \pm 0.02$ & $43.41 \pm 41.79$ & $1.11 \pm 0.37$ \\
U3 & $0.92 \pm 0.33$ & $0.02 \pm 0.01$ & $0.03 \pm 0.01$ & $1.22 \pm 0.15$ & $7.20 \pm 4.38$ & $0.63 \pm 0.27$ \\
Mean & $1.45 \pm 0.16$ & $0.22 \pm 0.04$ & $0.04 \pm 0.01$ & $2.61 \pm 0.51$ & $12.99 \pm 4.81$ & $0.75 \pm 0.08$ \\
P Value & 0.048 & 0.001 & 0.152 & 0.016 & 0.314 & 0.828 \\
\hline
\end{tabular}

SD: Standard deviation (Significant coefficients $P=0.05$ )

The mean levels of $\mathrm{Pb}$ in soil were within the WHO acceptable limit of $\leq 100$ (ppm). The highest value of $\mathrm{Pb}$ was recorded in $\mathrm{I} 3$ (Trans-Amadi) [3.50 $\pm 0.88 \mathrm{ppm}]$ (Table 2). Contamination of soil with $\mathrm{Pb}$ can be attributed to increased population, increased domestic wastes, chemical wastes from industries and transportation (Chen, Xia, Zhao, \& Zhang, 2010). Contamination of soils by $\mathrm{Pb}$ can also be attributed to wash off from paints (Hunt, 2016). The mean level of
$\mathrm{Cr}$ in soil was $0.27 \pm 0.03 \mathrm{ppm}$ which was within the WHO acceptable limit of $\leq 100$ (ppm). The highest values of $\mathrm{Cr}$ were recorded in CA; $0.45 \pm 0.18 \mathrm{ppm}$ and U2 (Diobu); $0.41 \pm 0.16 \mathrm{ppm}$ (Table 3 ). The findings of $\mathrm{Pb}$ and $\mathrm{Cr}$ are in agreement with the findings of (Yang, Lu, Long, Bao, \& Yang, 2011) where they described the top soil of the study areas as non-contaminated to moderately contaminated and therefore indicate moderate pollution. The mean levels of $\mathrm{Cu}$ in soil were 
within the WHO acceptable limit of $\leq 100$ (ppm). The highest values of $\mathrm{Cu}$ were recorded in I3 (Trans-
Amadi); 0.35 $\pm 0.01 \mathrm{ppm}, \mathrm{CA} ; 0.29 \pm 0.12 \mathrm{ppm}$ and U2 (Mguoba); 0.73 $\pm 0.25 \mathrm{ppm}$ (Table 2).

Table 3: Mean concentration $( \pm S E)$ of heavy metals in soil

\begin{tabular}{|c|c|c|c|c|c|}
\hline $\begin{array}{l}\text { Study } \\
\text { loc ations }\end{array}$ & $\mathrm{Na}$ (ppm) & $\mathrm{K}(\mathrm{ppm})$ & $\mathrm{Cr}(\mathrm{ppm})$ & Mn (ppm) & $\mathrm{Mg}(\mathrm{ppm})$ \\
\hline $\mathrm{CI}$ & $140.30 \pm 20.06$ & $13.21 \pm 6.29$ & $0.26 \pm 0.12$ & $2.74 \pm 0.05$ & $2.46 \pm 0.45$ \\
\hline II & $153.17 \pm 46.66$ & $1.87 \pm 0.11$ & $0.23 \pm 0.07$ & $4.19=0.23$ & $6.28 \pm 2.16$ \\
\hline D2 & $454.13 \pm 299.01$ & $2.52 \pm 0.23$ & $0.39=0.15$ & $5.90 \pm 0.60$ & $13.64 \pm 7.60$ \\
\hline B & $120.41=7.39$ & $1.70 \pm 0.45$ & $0.15 \pm 0.09$ & $1.68 \pm 0.02$ & $16.03 \pm 8.54$ \\
\hline $\mathrm{CA}$ & $96.08 \pm 8.39$ & $8.50 \pm 5.26$ & $0.45 \pm 0.18$ & $8.76 \pm 3.62$ & $23.45 \pm 12.17$ \\
\hline A1 & $113.17 \pm 31.43$ & $0.91=0.17$ & $0.14=0.05$ & $3.73=0.21$ & $7.50 \pm 3.60$ \\
\hline $\begin{array}{l}\mathrm{A} 2 \\
\mathrm{~A} 3 \\
\mathrm{CU}\end{array}$ & $\begin{array}{l}70.48 \pm 18.83 \\
143.63 \pm 92.38 \\
443.67 \pm 253.26\end{array}$ & $\begin{array}{l}2.54 \pm 0.25 \\
1.85 \pm 0.37 \\
9.66 \pm 3.76\end{array}$ & $\begin{array}{l}0.30 \pm 0.11 \\
0.28 \pm 0.16 \\
0.23 \pm 0.06\end{array}$ & $\begin{array}{l}4.03=0.51 \\
7.50 \pm 3.76 \\
1.54 \pm 0.67\end{array}$ & $\begin{array}{l}2.05 \pm 0.35 \\
10.94 \pm 5.52 \\
22.85 \pm 14.00\end{array}$ \\
\hline U1 & $68.33 \pm 7.54$ & $1.99 \pm 0.48$ & $0.19 \pm 0.11$ & $1.23 \pm 0.26$ & $4.77 \pm 1.24$ \\
\hline $\mathrm{U} 2$ & $138.01=3.12$ & $10.08 \pm 4.81$ & $0.41=0.16$ & $7.50 \pm 3.28$ & $23.04 \pm 7.22$ \\
\hline U3 & $142.30 \pm 19.93$ & $17.95 \pm 15.54$ & $40.26 \pm 0.15$ & $1.73=0.68$ & $9.46 \pm 2.55$ \\
\hline Mean & $173.64 \pm 35.31$ & $6.06 \pm 1.58$ & $0.27 \pm 0.03$ & $4.21=0.61$ & $11.87 \pm 2.10$ \\
\hline PV alue & 0.311 & 0.401 & 0.769 & 0.063 & 0.286 \\
\hline
\end{tabular}

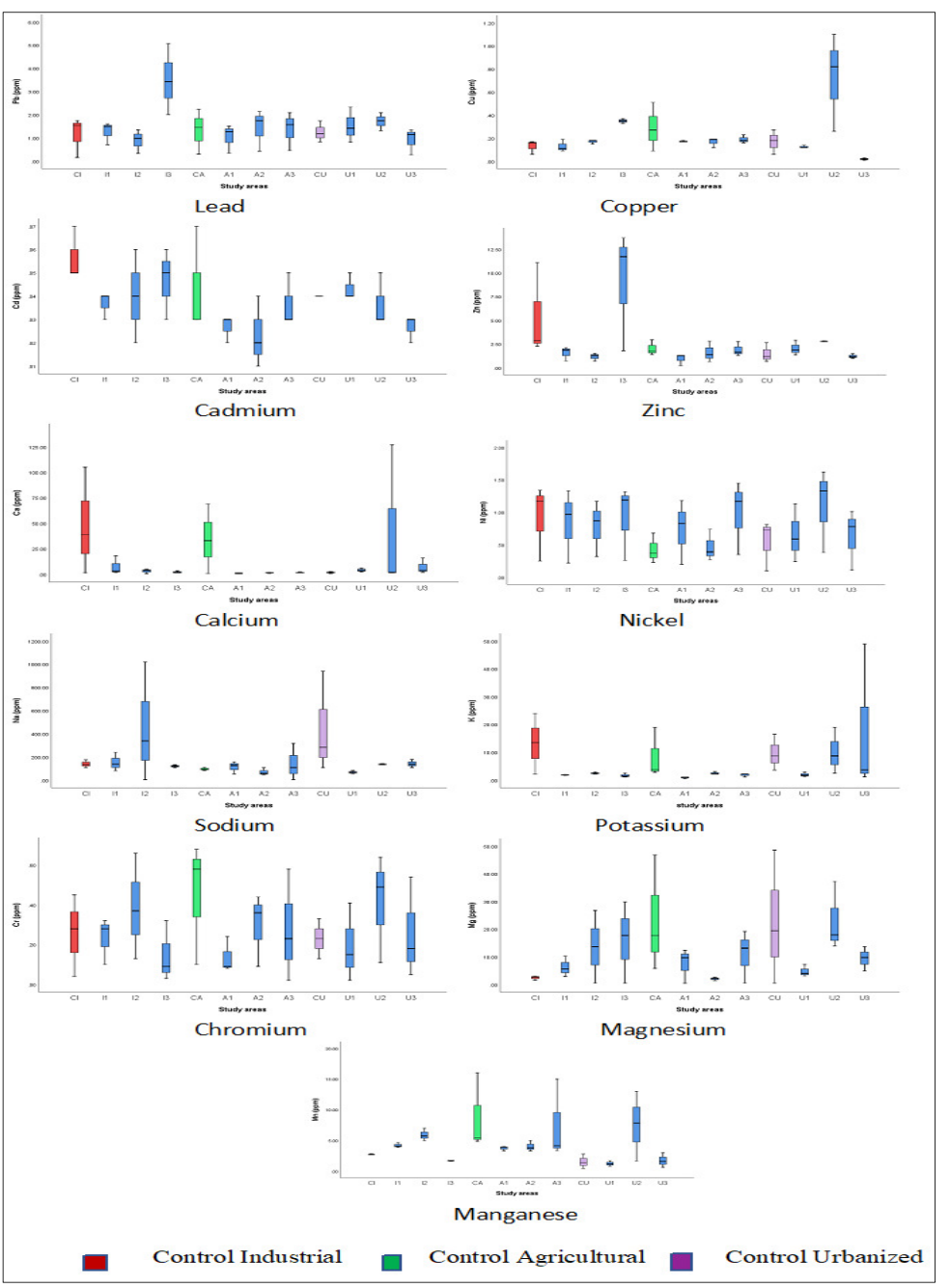

Fig 2: Variation in levels of metals 
Copper is fungicidal and is often used in fungicides. The findings contradict findings by Adrees et al., 2015 and Ballabio et al., 2018, who linked distribution of copper in soil to agricultural activities. Levels of copper in soil can also be influenced by geological factors, climate, pedological, agricultural and industrial sources. Erosion plays a key role in transfer of $\mathrm{Cu}$ and can be a source of contamination of soil (Minkina et al., 2017; Ballabio et al., 2018). Copper can be found as insoluble complexes that lowers its motility in soil (Brazauskiene, Paulauskas, \& Sabiene, 2008). The mean levels of $\mathrm{Cd}$ in soil were within the WHO acceptable limit of $\leq 3$ (ppm). The highest value was recorded in I1 (Onne); $0.06 \pm 0.01 \mathrm{ppm}$ while A2 (Eleme) recorded the least value of $\mathrm{Cd} ; 0.02 \pm 0.02 \mathrm{ppm}$ (Table 2). The findings can be related to findings of (Lu et al., 2010). Contamination of soils with cadmium is closely related to industrial activities in a particular area, for example metal processing industries. The mean level of $\mathrm{Zn}$ in soil were within the WHO acceptable limit of $\leq 300$ (ppm). The highest values of Zn were recorded in CI; $5.42 \pm 2.85$ ppm, and I3 (TransAmadi); $9.08 \pm 3.68 \mathrm{ppm}$ while A1 (Aluu) recorded the least value; $0.94 \pm 0.35 \mathrm{ppm}$ (Table 2). This can be attributed to heavy wash off from human settlements (Lu et al., 2010). The findings concur with findings of $\mathrm{Lu}, 2010$ where industrial activity influences the levels and distribution of $\mathrm{Pb}$ and $\mathrm{Zn}$ ( $\mathrm{Lu}$ et al., 2010). The mean levels of $\mathrm{Na}$ in soil were within the WHO acceptable limit of $\leq 100$ (ppm). The highest values of $\mathrm{Na}$ were recorded in I2 (Agbada); 454.13 $\pm 299.01 \mathrm{ppm}$ and CU; 443.67 $\pm 253.26 \mathrm{ppm}$ (Table 3 ). The findings agree with those of Liu, Rong, and Zhao, 2017, where values of $\mathrm{Na}$ and $\mathrm{EC}$ were affected by land use practices (Liu et al., 2017). The mean level of $\mathrm{K}$ in soil were within the WHO acceptable limit of $\leq 100$ (ppm). The highest values of $\mathrm{K}$ were recorded in $\mathrm{CI}$; 13.21 $\pm 6.29 \mathrm{ppm}$ and U3 (Mguoba); 17.95 $\pm 15.54 \mathrm{ppm}$ (Table 3). There was insignificant variation in levels of $\mathrm{K}$. This is in agreement with study by (Kihara et al., 2016). The variations can be attributed to land use practices, leaching and adsorption in soil (Kharal, Khanal, \& Panday, 2018). The mean level of Ca in soil were within the WHO acceptable limit of $\leq 100 \mathrm{ppm}$. The highest values of $\mathrm{Ca}$ were recorded in $\mathrm{C} 1$; $48.43 \pm 30.30 \mathrm{ppm}, \mathrm{CA} ; 34.32 \pm 19.65 \mathrm{ppm}$ and $\mathrm{U} 2$; $43.41 \pm 41.79 \mathrm{ppm}$ (Table 3 ). The mean level of $\mathrm{Ni}$ in soil was $0.7528 \pm 0.07580 \mathrm{ppm}$ which was within the WHO acceptable limit of $\leq 50 \mathrm{ppm}$. The highest value of $\mathrm{Ni}$ was recorded in $\mathrm{U} 2$ (Diobu); $1.11 \pm 0.37 \mathrm{ppm}$ (Table 2). The mean level of $\mathrm{Mg}$ in soil was $11.87 \pm$ $2.10 \mathrm{ppm}$ which was within the WHO acceptable limit of $\leq 100$ (ppm). The highest mean values of $\mathrm{Mg}$ were recorded in CA; $23.45 \pm 12.17 \mathrm{ppm}, \mathrm{CU} ; 22.85 \pm 14.00$ ppm and U2; $23.04 \pm 7.22 \mathrm{ppm}$ (Table 3 ). The findings agree with findings of De Bauw et al., that $\mathrm{Ca}, \mathrm{Mg}$ and $\mathrm{Ni}$ are varied in distribution and are affected by human and altitude differences (De Bauw, Van Asten, Jassogne, \& Merckx, 2016). The mean level of Mn in soil was $4.21 \pm 0.61 \mathrm{ppm}$ which was within the WHO acceptable limit of $\leq 2,000 \mathrm{ppm}$. The highest values of $\mathrm{Mn}$ were recorded in $\mathrm{CA} ; 8.76 \pm 3.62 \mathrm{ppm}, \mathrm{A} 3$; $7.50 \pm 3.76 \mathrm{ppm}$ and $\mathrm{U} 2 ; 7.50 \pm 3.28 \mathrm{ppm}$ (Table 3 ). The findings are in agreement with findings of Hassan et al., 2017 which were within range. The findings can be attributed to land use practices as revealed with the current findings where urbanized, industrialized and agricultural areas recorded varied findings (Hassan et al., 2017).

Conclusion: This study examines the Human Influence on Soil Metals Status in parts of Rivers State, Nigeria. Levels of $\mathrm{Pb}, \mathrm{Fe}, \mathrm{Cu}, \mathrm{Cd}, \mathrm{Zn}, \mathrm{Ca}, \mathrm{Ni}, \mathrm{Na}, \mathrm{K}, \mathrm{Cr}, \mathrm{Mg}$, $\mathrm{Mn}$, and $\mathrm{S}$ were determined in soils. Some parameters; $\mathrm{Pb}, \mathrm{Cu}, \mathrm{Cd}, \mathrm{Zn}, \mathrm{Ca}, \mathrm{Ni}, \mathrm{Na}, \mathrm{K}, \mathrm{Cr}, \mathrm{Mg}, \mathrm{Mn}$, and $\mathrm{S}$ recorded levels within permitted levels while some parameters; $\mathrm{Zn}$ and $\mathrm{Pb}$ recorded high levels above the permitted levels in I3 (Trans-Amadi). Cadmium (Cd) was recorded higher in industrialized areas as compared to urbanized and agricultural. Urban activities have highest influence in levels of Nickel in soil. The pollution of soils with metals in the studied sites is within permissible limits, however, levels of $\mathrm{Zn}, \mathrm{Cd}$ and $\mathrm{Ni}$ should be on close monitoring to in the industrial areas and urbanized areas. The study establishes that petroleum activities variedly affect the levels of metal pollution in urbanized, industrialized and agricultural areas.

Acknowledgement: This work was carried out within the PhD Program of World Bank African Centre of Excellence for Oilfield Chemicals Research, in line with the World Bank's mandate for establishing the African Centre of Excellence in University of Port Harcourt in Nigeria. The authors further acknowledge the Regional Universities Forum for Capacity Building in Agriculture (RUFORUM) through Dr. Odogwu A. Blessing and Prof. Ikechukwu O. Agbagwa of University of Port Harcourt for their continual mentorship and financial support under the Carnegie Post-Doctoral funding.

\section{REFERENCES}

Adrees, M., Ali, S., Rizwan, M., Ibrahim, M., Abbas, F., Farid, M., ... Bharwana, S. A. (2015). The effect of excess copper on growth and physiology of important food crops: a review. Environmental Sc.Pollut. Res. 22(11), 8148-8162.

Alghobar, M. A., \& Suresha, S. (2017). Evaluation of 
metal accumulation in soil and tomatoes irrigated with sewage water from Mysore city, Karnataka, India. $J$. Saudi Soc.Agric. Sci. 16(1), 49-59.

Balkhair, K. S., \& Ashraf, M. A. (2016). Field accumulation risks of heavy metals in soil and vegetable crop irrigated with sewage water in western region of Saudi Arabia. Saudi J. Biol. Sci. 23(1), S32S44.

Ballabio, C., Panagos, P., Lugato, E., Huang, J. H., Orgiazzi, A., Jones, A., Montanarella, L. (2018). Copper distribution in European topsoils: An assessment based on LUCAS soil survey. Sci. Total Environ. 636, 282-298.

Brazauskiene, D. M., Paulauskas, V., \& Sabiene, N. (2008). Speciation of $\mathrm{Zn}, \mathrm{Cu}$, and $\mathrm{Pb}$ in the soil depending on soil texture and fertilization with sewage sludge compost. J. Soils and Sediments, 8(3), 184-192.

Chen, X., Xia, X., Zhao, Y., \& Zhang, P. (2010). Heavy metal concentrations in roadside soils and correlation with urban traffic in Beijing, China. J. Hazard. Mat. 181(1-3), 640-646.

De Bauw, P., Van Asten, P., Jassogne, L., Merckx, R. (2016). Soil fertility gradients and production constraints for coffee and banana on volcanic mountain slopes in the East African Rift: A case study of Mt. Elgon. Agriculture, Ecosystems and Environment, 231, 166-175. https://doi.org/10.1016/j.agee.2016.06.036

Harmanescu, M., Alda, L. M., Bordean, D. M., Gogoasa, I., Gergen, I. (2011). Heavy metals health risk assessment for population via consumption of vegetables grown in old mining area; a case study: Banat County, Romania. Chemistry Central Journal, 5(1), 1-10. https://doi.org/10.1186/1752-153X-5-64

Hassan, M., Hassan, R., Pia, H., Hassan, M., Ratna, S., Aktar, M. (2017). Variation of Soil Fertility with Diverse Hill Soils of Chittagong Hill Tracts, Bangladesh. International Journal of Plant \& Soil Science, $18(1), \quad 1-9$. https://doi.org/10.9734/IJPSS/2017/34975

Hoornweg, D., Bhada, P. (2012). What a Waste. A Global Review of Solid Waste Management. Urban Development Series Knowledge Papers, 281(19), 44

Hunt, A. (2016). Relative bioaccessibility of Pb-based paint in soil. Environmental Geochemistry and Health, 38(4), 1037-1050.

Islam, S., Ahmed, K., Islam, S. A. (2017). Ac ce pt e us cr t. Pedosphere: An International Journal, 0160. https://doi.org/10.1016/S1002-0160(17)60394-1

Jaishankar, M., Tseten, T., Anbalagan, N., Mathew, B. B., Beeregowda, K. N. (2014). Toxicity, mechanism and health effects of some heavy metals. Interdisciplinary Toxicology, 7(2), 60-72.

Kharal, S., Khanal, B., \& Panday, D. (2018). Assessment of Soil Fertility under Different Land-Use Systems in Dhading District of Nepal. Soil Systems, 2(4), 57.

Kihara, J., Nziguheba, G., Zingore, S., Coulibaly, A., Esilaba, A., Kabambe, V., Huising, J. (2016). Understanding variability in crop response to fertilizer and amendments in sub-Saharan Africa. Agriculture, Ecosystems and Environment, 229, 1-12.

Li, S., Ma, Y. (2014). Urbanization, Economic Development and Environmental Change. Sustainability, 6(8), 5143-5161.

Liu, J., Rong, Q., Zhao, Y. (2017). Variations in soil nutrients and salinity caused by tamarisk in the coastal wetland of the Laizhou Bay, China. Ecosphere, 8(2). https://doi.org/10.1002/ecs2.1672

Lu, C. A., Zhang, J. F., Jiang, H. M., Yang, J. C., Zhang, J. T., Wang, J. Z., Shan, H. X. (2010). Assessment of soil contamination with $\mathrm{Cd}, \mathrm{Pb}$ and $\mathrm{Zn}$ and source identification in the area around the Huludao Zinc Plant. J. Hazard. Mat. 182(1-3), 743-748

Minkina, T. M., Pinskii, D. L., Bauer, T. V., Nevidomskaya, D. G., Mandzhieva, S. S.; Sushkova, S. N. (2017). Sorption of $\mathrm{Cu}$ by chernozems in southern Russia. J. Geochem. Explor. 174, 107-112.

Rahman, M. A., Rahman, M. M., Reichman, S. M., Lim, R. P., Naidu, R. (2014). Arsenic speciation in australian-grown and imported rice on sale in Australia: Implications for human health risk. $J$. Agric.Food Chem. 62(25), 6016-6024

United Nations Interagency Framework Team for Preventive Action. (2012). Renewable Resources and Conflict. Toolkit and Guidance for Preventing and Managing Land and Natural Resources Conflict, UN Interagency Framework Team for Preventative Action, 119. https://doi.org/10.1038/206985b0

Yang, Z., Lu, W., Long, Y., Bao, X., Yang, Q. (2011). Assessment of heavy metals contamination in urban topsoil from Changchun City, China. J. Geochem. Explor. 108(1), 27-38. 